\title{
Research on Government Public Employment Service Based on New Employment Form
}

\author{
Guo Rongli \\ School of Finance and Public Administration, Harbin University of Commerce \\ P.R.China, 150028 \\ grlcsw@163.com
}

\begin{abstract}
With the development of the Internet, there is a new situation in the field of employment, called the new employment form. It is increasingly important to change the public employment service under the new employment form to better help the development of the new form. This paper expounds the concept, scale and form of new employment by means of literature analysis, analyzes the current situation and existing problems of public employment in new employment, and puts forward the concept of new employment service policy. The measures such as adjusting the social security system, increasing the government's supervision over new-type enterprises and setting up a platform for releasing new-type employment information, can contribute to the development of new formats.
\end{abstract}

Keywords-Public employment services; New Employment Forms; Policies

\section{THE CONCEPTUAL PROPOSAL OF NEW EMPLOYMENT} FORMS

Public employment policies aim to address the unemployment problem. From the establishment of the new China to the present, our government continuously established a series of employment service policies which were based on Chinese actual situation to solve the unemployment problem. In 1949, in order to solve the unemployment problem, the Chinese government put forward an employment service policy to realize full employment of urban workers. To solve the problem of unemployment caused by the educated youth back to the city in 1980, under the direction of national overall planning, the government presented an employment policy. The policy combined three employment ways which are introducing by the labor department, working in voluntary organizations, and self-employment. This policy changed the traditional employment awareness. In 1998, to solve the plenty of laid-off workers re-employment problem, the State Council issued a Notice on the basic living guarantee and reemployment of laid-off workers from state-owned enterprises. The government activated the employment marketization policy and laid-off workers re-employment safeguard policy [1]. In 2015, the State Council issued Guidance on actively promoting "Internet + " action and pointed out that "Internet + " concept applies not only to the development of the economy but also to upgrade and reform in the field of educational services [2]. After these, in the Communique of the Fifth Plenary Session of the 18th CPC central committee and the 2016 Government Work Report first proposed the concept of
"New Employment Forms" which called for enhanced support for flexible employment and New Employment Forms. As a new way to distribute labor resources, the New Employment Forms have had a huge impact on the existing economic and social operation and economic subjects' behaviors. "New Employment Forms" is working under the intellectualization, digitization, and informatization of product means which is driven by the new round of industrial revolution. It is a work mode that realizes the flexible collaboration between virtual and physical production system.

\section{THE DEVELOPMENT SCALE AND FORM OF NEW EMPLOYMENT FORMS}

\section{A. The development scale of New Employment Forms}

Currently, due to the whole society entered the Mobile Internet Era, market transaction costs declined sharply and the work mode of sharing economy which connects the supply and consumption ends with Internet platforms is booming. According to the 40th China Internet Development Statistics Report, as of June 2017, China's Internet penetration rate reached $54.3 \%$, the number of netizens reached 751 million. Application user scale in Internet public service sector continuous grows, such as the user scales of online education services and online booking car services reached 144 million and 495 million separately; online shopping, online takeout and online travel booking user scale growth were $10.2 \%, 41.6 \%$, and $11.5 \%$ separately. The consumption of online shopping market shows obvious upgrade features [3]. Due to the low threshold, little investment, and quick returns of e-commerce, it is the best employment platform for young people who have no working experience and lack of rich start-up capital, such as Taobao online stores. According to the statistics of China Microboss Industry Development Research Report 2016 released by Internet Society of China, there were more than 15.38 million sellers in 2016. The overall market reached 360.73 billion RMB [4]. New materials, 3D printing, and other technology further change the macro industrial production model. Students with an abundant computer and business management knowledge are also more inclined to use the Internet platform with their special professional skills, selfstudying web design, programming design and so on. The development of New Employment Forms in China shows an explosive growth trend. 


\section{B. Manifestation of New Employment Forms}

With the Internet sharing economic developing, New Employment Forms continue springing up. The development of industrial intelligence makes a lot of traditional positions declining. The main jobs of many workers become the maintenance and upgrading of programs and systems. Based on the current development situation, the manifestation of New Employment Forms will be summarized as follows:

One is the Internet gave birth to the Digital Quotient. The rise of big data industry has leveraged a trillion-dollar market. The Big data industry involves every section of data collection, processing, conduction, analysis and application, and circulation transactions. Therefore, it brought a lot of employment opportunities. The Digital Quotient is an innovative entrepreneurship model which is based on big data and supports the Big Data application development and Big Data collection. The second is a freelancer. A freelancer means an employee who is not affiliated with any organization and does not make any long-term commitment to any employer. Such as micro boss who do not go to specific places and without limitations of working hours.no restriction on personal freedom. The third is the multiple identities professionals. "Multiple identities professionals" means that a person is simultaneously engaged in a variety of work, he or she switches identities among his or her several types of workplaces. The fourth is new forms of employed professionals. They are mainly from the large-scale development of labor service positions which are derived from the network of online business, such as the delivery men for the delivery platforms and courier. On the basis of traditional employment, the New Employment Forms have added many new elements to better meet the needs of economic diversification and demand diversification. New Employment Forms show new characteristics that are different from the traditional employment, such as Internet-based opportunities, task fragmentation, job flexibility, identity personalization, etc. Based on the manifestation of New Employment Forms and the highlights of the new features, some new challenges are put forward to the traditional public employment service policy.

\section{THE CURRENT SITUATION OF PUBLIC EMPLOYMENT SERVICES UNDER THE NEW EMPLOYMENT FORMS}

New Employment Forms adds many flexible jobs which increase the chances for disadvantaged employment. Helping each other with sharing through online platforms also contributes to enhancing professional skills in specialized fields In a certain extent, the New Employment Forms solved the employment issues for some people. Government departments strongly support to develop these New Employment Forms.

\section{A. Employment preferential policies are open to companies with New Employment Forms}

In order to encourage the development of New Employment Forms enterprises, the government takes the lead in purchasing related products and services. The government said that new business enterprises which meet the conditions can enjoy the related preferential policies of innovation and development. Online shop owners can apply for special start- up loans special venture loans. Aiming at Internet employment groups, entrepreneurial groups, and other flexible employment staff, Human Resources and Social Security Department formulated a policy on expanding insurance participation in 2017. The policy defined the New Employment Forms companies can enjoy the financial and credit policies as the other companies.

\section{B. Establish rules and regulation to regulate New Employment Forms}

Online taxis reserving services and delivering men are new employment positions which are derived from the New Employment Forms The policy brought people convenience. It is at the beginning of New Employment Forms where the standardization of employment needs to be strengthened. The illegal online reserving taxi issues frequently appear and the dispute occurs as the labor relations between drivers and platforms are fuzzy. Based on these issues, on October 10th, 2015, the Ministry of Communications established online reserving taxi platform administrative measures to clarify that platform operators are required to sign labor contracts with their drivers. In addition, in 2017 the State Council issued Opinions on the current period and future employment and entrepreneurship work. It explicitly supports the development of emerging industries, proposes to improve the entrance management of emerging industries, and stronger oversight will be exercised over delegated matters when they are being handled and after they have been handled. The government public service department needs to establish "Internet + "public employment and business venture service platform to promote service extend to mobile terminal, self-service terminal, and so on; improve the statistical monitoring system and explore to establish the New Employment Forms, labor entrepreneurship, and other business statistics monitoring indicators; expand employment data and information source to provide strong support for the implementation of accurate service.

\section{THE EXISTING ISSUES OF PUBLIC EMPLOYMENT SERVICE UNDER THE NEW EMPLOYMENT FORMS}

According to a survey retrieved from Human Resources and Social Security Department, in 2015, the self-employed people, part-time employees, and other forms of employment in non-agricultural employment accounted for $26.5 \%$, increasing $2.3 \%$ over 2014 [5]. If coupled with the situation of part-time employment workers, New Employment Forms gradually becomes a significant channel to expand employment Therefore, the public employment service demands and its related problems are more and more highlighted.

\section{A. The enthusiasm of New Employment Forms people on joining to social insurance is not high}

Now the employment of New Employment Forms companies, the payments of social insurance-related expenses, and employment support policies of the government are all transformed from the traditional employment level. Therefore, the employees who didn't sign the labor contracts in traditional employment industry transformed to New Employment Forms enterprises will be difficult to enjoy the related policies due to the unclear relationships and other problems. New 
Employment Forms industry workers, especially self-employed workers and multiple occupations workers have less active and enthusiastic about social insurance payments. Such as takeaway industry, how many takeaway orders are able to hold for one person is entirely up to the delivery man? In order to deliver in the regulated time, the takeaway staff's driving speed is very fast and running a red-light phenomenon is serious. There is a high degree of security risks. Whether the accident can be counted as occupational injuries, is not clear. Many New Employment Forms workers have weak awareness on signing a labor contract. Their own rights and interests cannot be protected as well as ruled.

\section{B. Lack of the integrity management and supervision on New Employment Forms by the government}

The Internet-based relationship between the New Employment Forms workers and the Internet platform organizations cannot be defined by the existing laws. New employment forms' workers are free to determine their own working hours, arrange their own work date, the income comes from the sharing among the sharing platform, such as microbusiness. There are much more people are working at online micro-business. While the consumers can't see the real products which the micro-boss sells before purchasing, they don' t have clear returning channel if they are not satisfied after they purchased. With the high imitation goods, the goods from the micro-bosses who are tracing money are hard to tell the truth. Even most of these goods are imitation. In the news, it is often revealed how harmful cosmetic products are to users. Many micro-bosses do not understand the product by themselves, and even never used the products they sell. They simply copy and forward the ads which the higher agents posted and have low attention to the results after using the products.

E rent treasure, takeaway black dens, the agents conceal the real information and mislead consumers to purchase, and other events result from the lack of the integrity management and supervision on New Employment Forms by the government. New Employment Forms' enterprises have a low threshold to set up which also reduce the company's integrity burden. With the same reasons, some companies open fraud annual reports. After cooperating with the Internet, some traditional industries pursue too much expansion, hunt too much market interests, and abandon the most basic integrity. For this New Employment Forms, whether to carry out pre-regulation, there are no clear requirements of the relevant laws and regulations.

\section{THE BLUEPRINT OF NEW EMPLOYMENT FORMS SERVICE POLICIES}

With the increasing global competition, the number of flexible workers is increasing and the government is attaching more and more important to improve the quality of employment through more active public employment services.

\section{A. The Human Resources and Social Security Department adjusts the social system}

The Human Resources and Social Security Department should adjust the traditional means of employment and the labor relations and social security system, open up new space, and improve the new employment and social security system to adapt to the characteristics of New Employment Forms. For example, clear the path of the employees' participating in social insurance and submitting the payment of housing accumulation fund; sign up labor contracts with New Employment Forms' enterprises and participate in social insurance under the law; for eligible enterprises, enterprises can enjoy employment subsidy policies. To the other workers who did not sign labor contracts, the employment unit should pay corresponding social insurance according to the standard of flexible employment. It should also explore the protection for flexible workers about their unemployment and injury insurance, mainly to figure out whether accidents of unsigned labor contracts employees occurred during work are included into occupational injuries. Secondly, carry out the "Internet + government" operation and comprehensively implement the relevant issues related to public employment services on the Internet. These would save manpower and resources. Therefore, the "Internet + government" could encourage the development of New Employment Forms.

\section{B. Increase the supervision on New Employment Forms' enterprises by the government}

Take the micro-business as an example to illustrate this opinion. With the rise of the micro-business market, low-cost Internet start-ups have also become increasingly popular. In order to regulate the industry, the country should gradually introduce the specific legal regulations. To eliminate the problem of micro-business and online shops selling fake products. We will build a healthy and safe New Employment Forms' circle of micro-business. The government should introduce appropriate policies to encourage people to use the Internet to start employment to expand employment channels. Strengthen supervision over the safety of goods, increase the level of inspection of online production and business operations, and ensure the safety of website merchandise sales. When merchants apply for only online sales, network managers should strictly control and verify the authenticity of uploading documents. It is better to conduct on-the-spot verification and strengthen supervision. The departments of supervision, commerce, agriculture, and law can work together to increase supervision. You can set up a unified product code for each commodity, and the scan of the product safety information can be used to get the information of the manufacturer.

\section{Build an information distribution platform for New Employment Forms' jobs creation}

The government can assist or organize to establish a new job information release platform to collect the information on the employment of unemployed workers and companies' recruitment information and detailed records of job seekers' intention and labor skills. Recommend the appropriate positions for those who have working intentions. To people who have to introduce the preferential policies of 
entrepreneurship, connect them with the enterprise units that can provide help. Provide occupation Training to those employees or initial workers who lack technology. Take special care of the poor families and implement one on one service to help them find their jobs which they can do. Through the employment support policies to encourage enterprises and institutions to actively submit job information, and actively employ the people mentioned above, such as employment services subsidies, public welfare jobs subsidies, small secured loans, and low-profit items discount, administrative fees rebate, and other means.

\section{CONCLUSION}

In summary, the New Employment Forms expand employment channels, and have become an important way to solve unemployment. Flexible and free employment is widely welcomed. Meanwhile, the social problems brought up by the employment forms cannot be ignored. At present, there is a clear policy restriction on the online reserve taxies. The eligible New Employment Forms' enterprises can also enjoy preferential policies. However, there still lack studies on the regulation of the entry and exit mechanism and the supervision of the New Employment Forms' physical stores. The relevant government departments should issue regulations to solve specific problems and multi-sectoral assistance to help the development of New Employment Forms. The development of new forms of development space will not be limited to the visible employment level. The role of services is also a considerable perspective. Therefore, it is a wide research area on the employment public service policy under the New Employment Forms.

\section{ACKNOWLEDGMENT}

Introduction of writer: Guo Rongli (1977- ), female, Han, born in Heilongjiang Fujin, associate professor of Harbin University of Commerce, Ph.D., master tutor. Research orientation: The social security theory and practice.

Fund Project: Harbin University of Commerce subject project: public service policy research of supporting new employment (2016001).

\section{REFERENCES}

[1] Liu, C. The Era of "Internet + " on the cultivation of university students' entrepreneurship [J]. Journal of Jilin University Architecture, 2015 (5).

[2] Wei, W. \& Huang, Q. Cloud computing technology and cloud intelligence [J]. Journal of Xi'an Institute of Posts and Telecommunications, 2010 (6).

[3] Bian, S, etc. The application research of "Internet + entrepreneurship" practice teaching method in Teaching of E-commerce [J]. Macroeconomic Management, 2017 (1).

[4] People's Republic of China Ministry of Labor and Social Security. Labor market regulations. Retrieved from http://www.suifenhe.gov.cn/contents/1383/6164.html.

[5] China Internet Network Information Center. The 40th China Internet Development Statistics Report [EB / OL]. Http://cnnic.cn/gywm/xwzx/rdxw/201708/t20170804_69449.htm. 